\title{
The Religion of Confrontation: Concepts, Violence, and Scholarship*
}

\author{
Nancy Levene \\ Yale University; nancy.levene@yale.edu
}

\begin{abstract}
Jonathan Z. Smith's essay “Religion, Religions, Religious" discovers the invention of religion as a generic term in colonial adventure. The move is notable: religion is born in violence, but it can be repurposed as a term without determinate content by which to compare cases. Smith's origin story is to empower scholars to pick up "religion" as they do the terms "language" and "culture." There are reasons, however, not only to revisit the story but also to ask whether it is not missing a move - whether the reclamation of a violent term requires more from the scholar than Smith's structuralist reversal, his reinvention of colonialist invention. I compare Smith's resourcefulness with the conquistadors to Edward Said's critique of Orientalism. Both thinkers are asking questions of violence, invention, and use. Said more squarely addresses problems of thinking with and beyond guilty concepts. Yet Smith's story is an important counterpoint. Together, these thinkers help the humanities lay ground for a more expansive and self-conscious theoretical future.
\end{abstract}

\section{Keywords}

Orientalism, power, religion, critique, interpretation, Jonathan Z. Smith, Edward Said

* This article was developed from remarks given at a panel on Jonathan Z. Smith's pedagogy. Thanks to my fellow panelists, Christopher Lehrich, Kathryn Lofton, and Kurtis Schaeffer, and to the anonymous reviewers for their helpful comments.

HTR 113:1 (2020) 111-137 
I thought that if I could put it all down, that would be one way. And next the thought came to me that to leave all out would be another, and truer, way.

clean-washed sea

The flowers were.

These are examples of leaving out. But, forget as we will, something soon comes to stand in their place. Not the truth, perhaps, but-yourself. It is you who made this, therefore you are true. But the truth has passed on

to divide all.

- John Ashbery ${ }^{1}$

\section{Fabrication}

In 2013, Jonathan Z. Smith published a collection of essays on the challenges of teaching religion in higher education. ${ }^{2}$ The essays stem from Smith's interest in how the religion major might serve as an introduction to common problems in humanistic learning, such as the identification of cases and canons, the translation of diverse materials, and the awareness of how the history of scholarship shapes what learners encounter in the texts and artifacts of others. The values he proffers include preparation, comparison, and interpretative decision. Together, these underscore one further fundament of the humanities: the importance of being alert to the elementary power of the mind to shape what one sees. It is "by an act of human will, through language and history, through words and memory, that we are able to fabricate a meaningful world and give place to ourselves." 3 Smith cites the classic dilemma that, although language is how human beings encounter the world, "words are not after all the same as that which they name and describe."4 It is striking, therefore, that, as he puts it, "education comes to life at the moment of tension generated by the double sense of 'fabrication,' for it means both to build and to lie." 5

Smith's 1998 essay on the history of "religion" as a word and object of study, "Religion, Religions, Religious," presents a singular opportunity to investigate what is involved in the work of fabrication. ${ }^{6}$ His essay identifies the emergence of the

${ }^{1}$ John Ashbery, "The New Spirit," in Three Poems (New York: Ecco, 1970) 3-51, at 3.

2 Jonathan Z. Smith, On Teaching Religion: Essays by Jonathan Z. Smith (ed. Christopher Lehrich; Oxford: Oxford University Press, 2013).

${ }^{3}$ Ibid., 14.

${ }^{4}$ Ibid.

${ }^{5}$ Ibid. On Smith's interest in the mischief of words, see Karen L. King, "Comparison: Categories, Methods, and Mischiefs-The Case of the Gospel of Judas," in Introducing Religion: Essays in Honor of Jonathan Z. Smith (ed. Willi Braun and Russell T. McCutcheon; London: Equinox, 2008) 178-91. On the particular mischief stemming from the study of Christian origins, see Smith, Drudgery Divine: On the Comparison of Early Christianities and the Religions of Late Antiquity (Chicago: University of Chicago Press, 1990).

${ }^{6}$ Smith, "Religion, Religions, Religious," in Critical Terms for Religious Studies (ed. Mark C. Taylor; Chicago: University of Chicago Press, 1998). The essay is reprinted in the collection of 
concept of religion as a generic term in early modern colonial adventures. Religion and related words, he argues, possess historically specific and politically contentious baggage. This beginning has become the familiar move of an academic literature whose aim is to consider the equivocal legacies of the words, distinctions, and fields that characterize the scholarly landscape. But Smith's wager is surprising given the tendency of this literature to linger in the mode of exposure. He suggests that, in ridding ourselves of the illusion of their neutrality, we can recover such words to understand the world, not as compromised descriptors, hedged by quotation marks and implicit apologies, but as neutral in a second sense, as generic. Generic here denominates the product of lifting a word from its home context for the purpose of understanding multiple contexts. It affords the organization and reorganization of the world in ways that contend with the mutually adaptive relationship between words and things. The principal advantage of this move is the possibility of comparison, the generic term's strategic mobilization of phenomena to the end of seeing one thing newly in the light of another.

Religion taken as a generic term of comparison can be criticized from several angles. How can such a term be faithful to history? What assumptions does the very idea of a generic smuggle into a given case? What does this religion have to do with the contexts from which it is lifted? "Religion, Religions, Religious" is a theoretical contribution to these questions. It is a history that, in homing in on a single instance, a single usage, hopes to show what any history of religion would need to be: self-conscious not only of what the word religion helps scholars to see about the world, but also what the word has helped others to see. How will we relate to those others? More pointedly, how does one recover concepts that are born or used in violence? Religion might refer to a variety of things; it has been used in a variety of ways. The question Smith's history raises is: Insofar as the word religion bespeaks a kind of violence, what should we do about that? This has been a question in postcolonialist criticism, as in all critical gestures that seek to acknowledge the sins of the past in light of the pressures of the present.

Smith's reply is not a prosecutorial drive to retry the concept of religion, nor even a pragmatic defense of it. He does not lean on his oft-quoted maxim that "religion is solely the creation of the scholar's study." In "Religion, Religions, Religious," religion is not a creation of the scholar but of the conquistador. ${ }^{8}$ For that very reason, Smith holds, it is ours to use. There is no need to stage a confrontation with the guilty party. In the language of double fabrication: they lie, we build.

Smith's essays, Relating Religion: Essays in the Study of Religion (Chicago: University of Chicago Press, 2004). Page numbers refer to the latter volume.

${ }^{7}$ Smith, introduction to Imagining Religion: From Babylon to Jonestown (Chicago: University of Chicago Press, 1982) xi-xiii, at xi.

${ }^{8}$ I employ the term conquistador following Smith's usage and argument. This is not to assert that what was undoubtedly a complex cultural encounter can be exhaustively described with this single focus. It is to use conquistador as Smith does - as a trope for thinking about elements of the encounter that embed in our terms. 
The surprise of Smith's claim has been diminished in the absorption of religion as a generic term suited to compare - a term of none to understand all. " "Religion, Religions, Religious" is also associated with treatments of the politics of religion's formation and circulation. ${ }^{10}$ However, the essay's contribution exceeds the concerns of both literatures, giving the humanities not only a history of religion but a theory of concepts - a theory of how to put their fabrication to work. To get to this broader point, I consider Smith's idea of a generic religion: where Smith thinks this idea comes from, what it solves for him, and what problems it raises for the study of religion as well as the retrieval and usage of concepts more generally. For Smith, the generic usage is fortuitous precisely because of its shady origins. I argue that to understand what is generative in Smith's position is also to find that it calls for a supplementary critical standpoint, one attuned to the scene of confrontation at the heart of Smith's story. Smith identifies a religion of confrontation, but he forfeits his own confrontation with his opponent. The consequence of this forfeiture is visible in following how he rescues the usage he wants.

To illuminate this consequence and its required supplement, I contrast Smith with one of his theoretical contemporaries in the politics of the humanities, Edward Said. Whereas Smith practices fabrication as calling for distance from the world, leaving "all out," to use John Ashbery's image, Said would thin the membrane separating, as he puts it, "the world, the text, and the critic." change of register - "It is you who made this, / therefore you are true"-and his realization, "But the truth has passed on / to divide all." ${ }^{\prime 2}$ Poets may not be theorists (and vice versa), but the fragment from "The New Spirit" activates the scene. To enter its logic is to conceive a way forward in the critical history of religion. The subjection of Smith and Said to this comparison is itself a fabrication, but I hope to gain a theoretical advance in line with their shared use of models and metaphors.

How, then, does theory navigate fabrication, including its own $?^{13}$ The question calls for attention to the relation of concepts, violence, and scholarship.

\footnotetext{
${ }^{9}$ The use of religion as a generic term is embattled in theoretical literature. See, for example, the essays in Guide to the Study of Religion (ed. Willi Braun and Russell T. McCutcheon; New York: T\&T Clark, 2000). It functions nevertheless to name the field of the study of religion, departments of religion, and academic bodies such as the American Academy of Religion. Smith's oeuvre is the most elaborated defense of this function, while also calling, I argue, for a connection to critical theory.

${ }^{10}$ Exemplary works are Bruce Lincoln, Discourse and the Construction of Society: Comparative Studies of Myth, Ritual, and Classification (New York: Oxford University Press, 1992); Talal Asad, Genealogies of Religion: Discipline and Reasons of Power in Christianity and Islam (Baltimore: Johns Hopkins University Press, 1993); and Tomoko Masuzawa, The Invention of World Religions, or How European Universalism Was Preserved in the Language of Pluralism (Chicago: University of Chicago Press, 2005).

${ }^{11}$ Edward Said, The World, the Text, and the Critic (Cambridge: Harvard University Press, 1983).

${ }^{12}$ Ashbery, "The New Spirit," 3.

${ }^{13}$ Jacques Derrida gives a generation-orienting account of this question in contending with the inheritance of structuralism, the theoretical tradition with which both Smith and Said sympathize (see Derrida, "Structure, Sign, and Play in the Discourse of the Human Sciences," in Writing and Difference [trans. Alan Bass; Chicago: University of Chicago Press, 1978] 278-93). Tomoko Masuzawa
} 


\section{Violence and Theory}

In "Religion, Religions, Religious," Smith locates the emergence of religion as a generic term in the crucible of the conquest of the Americas. "Religion," he holds, stems from the Latin Christian religio, used in monastic contexts in the ancient and medieval worlds and then gradually widening to include others. An alternate history would see that religion is also invented in colonial confrontation, taking on for the first time its meaning of a set of practices and beliefs concerning spiritual realms held by distinct communities, and universalizable, or almost so, as an inheritance of the human condition. ${ }^{14}$ It is this qualified universal that Smith draws our attention to. He observes that religion is invented not only to name what is foreign but also to exclude it, even as the term is then deployed to compare a multitude of things. Those natives do not have religion; therefore, there is religion. Smith traps the conquistador in this contradiction of ascription and withholding: how convenient is the inclusive term religion at the very moment when it appears "they" do not have one. He then diverts the conquistadors' invention, transposing what functioned as a divisive weapon into an empty category within which all forms of human collective practice, including the privileged Western kind, might be thrown together and compared. It is the scholar who shall be conquistador in this transposition, posing questions, naming and renaming the world. This is a form of theoretical revenge, consistent with the move Smith makes in picking up the double meaning of fabrication. Good scholarship will refuse to divide between us and them in having wrested the terms of study from them for us.

Smith's observations are consistent with a mood that finds religion (word and thing) a key player in any operation of distinction, from Orientalism to periodization to pluralism and globalization. Religion drags along historical content in its usage, which in turn affects the identification of instances of it, but it is also supremely mobile and opportunistic. Smith's work to map the invention of religion is to do for religion what theorists such as Benedict Anderson, Eric Hobsbawm, and Jean-François Bayart have done for nationalism: to show its seams and sleights, to understand its creation and circulation. ${ }^{15}$ This kind of work is of long-standing

modifies Derrida in bringing his claims to the study of religion (see Masuzawa, "Theory without Method: Situating a Discourse Analysis on Religion," in Religion and Society: An Agenda for the $21^{\text {st }}$ Century [ed. Gerrie ter Haar and Yoshio Tsuruoka; Leiden: Brill, 2007] 173-204; and eadem, "Reader as Producer: Jonathan Z. Smith on Exegesis, Ingenuity, and Elaboration," in Introducing Religion [ed. Braun and McCutcheon] 311-39). The present essay is seeking an alternate "post" structuralism.

${ }^{14}$ In "A Pearl of Great Price" (in Imagining Religion, 90-101), Smith writes, "The myth of Hainuwele is not . . . primarily concerned with the discrepancy between the world of the Demaancestors and the world of men. It is, I would suggest, concerned with the discrepancy between the world of the European and the world of the native; it is a witness to the confrontation between native and European economic systems" (98).

${ }^{15}$ Benedict Anderson, Imagined Communities: Reflections on the Origin and Spread of Nationalism (New York: Verso, 1983); The Invention of Tradition (ed. Eric Hobsbawm and Terence Ranger; Cambridge: Cambridge University Press, 1992); Jean-François Bayart, The State in Africa: The 
importance in the humanities and social sciences. There have now been several generations of scholars working to trace the social work of concepts in various political, cultural, and economic ventures.

However, Smith is not simply an inheritor of postcolonial studies, repurposing this discourse for the study of a particular item: religion. ${ }^{16}$ He makes religion both the target concept and also the solution. Religion comprises the semantic field in which colonialism simultaneously happens and, unwittingly, we will see, ends. In one tradition of critical theory, this might be framed as: colonialism gives birth to its own overcoming, the colonized overthrowing the system, the system having corroded from within. Smith's story is different. Colonialism gives rise to the science that it already unwittingly is. Notably, this is to say, Smith does not construe the dynamic at issue in the manner of critique. It is not that colonialism gives rise to its own contradictions and limits, or fails to do so, as criticism might expose. Nor does its structure bespeak a more paradoxical knowledge that "heals the wound that it itself is," as Hegel puts it. ${ }^{17}$ In Hegel's phrase, knowledge, or consciousness, awakens from its slumber as the call to account for and transform its originaccount for existence, one's own and that of others, and thus to reckon with one's evil, one's colonialism, so to speak. Consciousness awakens and accounts, or it fails to, wreaking havoc on itself and others. In a certain religious idiom, this is to put the sinner in a relation of responsibility for sin; in secular and psychoanalytic terms, it is critique as involved in the structure of what is being criticized, critique as immanent but not ineluctable, in which it is possible to disavow one's knowledge but thus also to take it up anew. Humanity "must make itself what it is." must, in Smith's terms, fabricate itself. This is the wager of self-consciousness, if equally self-deception: that a system, person, or culture can hide from itself, can, to paraphrase Kierkegaard, will not to be itself. ${ }^{19}$

Smith's use of fabrication seems to appreciate the power of this thought. But the colonialist position in Smith's hands is notably neither conscious nor unconscious, neither critical nor disavowed. Its contradictory "religion" is already the position that vanquishes religion as colonialism — it is already the position of scholarship — only

Politics of the Belly ( $2^{\text {nd }}$ ed.; Wiley, 2009); and idem, The Illusion of Cultural Identity (trans. Steven Rendall et al.; Chicago: University of Chicago Press, 2005).

${ }^{16}$ For studies of religion and postcolonialism see David Chidester, Empire of Religion: Imperialism and Comparative Religion (Chicago: University of Chicago Press, 2014), and Richard King, Orientalism and Religion: Postcolonial Theory, India, and "The Mystic East" (New York: Routledge, 1999).

${ }^{17}$ G. W. F. Hegel, Lectures on the Philosophy of Religion (3 vols.; ed. Peter C. Hodgson; trans. R. F. Brown, P. C. Hodgson, and J. M. Stewart; Berkeley: University of California Press, 1985) 3:106.

${ }^{18}$ Ibid., 303.

${ }^{19}$ Søren Kierkegaard, The Sickness unto Death (ed. and trans. Howard V. Hong and Edna H. Hong; Princeton: Princeton University Press, 1981) 13. Kierkegaard identifies a three-fold concept of despair: "in despair not to be conscious of having a self," "in despair not to will to be oneself," and "in despair to will to be oneself" (13). 
in that it is never anything but colonialism. One might call this invention without critique. Or perhaps invention by accident, reclaimed as scholarly ingenuity.

Compare Edward Said's position on Orientalism, a term that refers to the West's modes of "dealing with the Orient - dealing with it by making statements about it, authorizing views of it, describing it, by teaching it, settling it, ruling over it: in short, Orientalism as a Western style for dominating, restructuring, and having authority over the Orient. ${ }^{.20}$ The contrast with Smith lies in the idea that Orientalism possesses a curious instability. It is tenacious, permanent until such a time as the system's very success overwhelms its functioning. The West invents its other, but then is also threatened by it. The suppression of the other is never complete, if indeed it ever arrives at the other at all, and therefore is both total as a fantasy and also in reality insecure. This worry extends to the critic of Orientalism, who is conscious that the critique itself might not escape the terms of what is criticized; it might merely perpetuate the suppression of the other, either in the name of this other or in that of the critic. Perhaps the other must not be represented at all. ${ }^{21}$ Perhaps this is so even if this other is one's very self. Perhaps Hegel is wrong about the dynamism of knowledge, pain, and criticism; perhaps knowledge is simply and only a wound, a diremption in reality that consciousness can never heal.

Smith's position is absent these anxieties. It is not directly a critique of colonialism, but neither is it agnostic on the point. I will observe how it works in the first two paragraphs of "Religion, Religions, Religious," which introduce the invention of religion in the context of colonialism and its aftermath. The first paragraph relates the idea that the term religion is called upon both to explain others and to differentiate them from Western forms of thought and life. Smith's claim is not that religion is a Western term that distorts the thing under scrutiny. ${ }^{22}$ It is not that conquest is the outcome of the Western term and form of life. It is that the term religion is generated, converted from other usages, in the act of conquest. Unlike the violent projection denoted by the term Oriental, however, religion can be recovered - as if the very violence by which it is promulgated can be harnessed for another end.

${ }^{20}$ Edward Said, Orientalism (New York: Vintage Books, 1978) 3.

${ }^{21}$ As one of the epigraphs to Orientalism, Said appends Marx's observation of mid-1 ${ }^{\text {th }}$-century small peasants in France: "They cannot represent themselves; they must be represented." The line is from the "Eighteenth Brumaire of Louis Bonaparte," and refers to conditions leading up to Bonaparte's coup d'état in December 1851 (see The Marx-Engels Reader [ed. Robert C. Tucker; New York: Norton and Co., 1978] 608). For both Marx and Said, this observation galvanizes their critical gestures. Marx makes self-representation a question of the conditions under which the small peasants can form a class. Said indicts the Western machine of othering to question what would be involved in a common consciousness, a common representation.

${ }^{22}$ This distortion is what is at issue in Asad, Genealogies of Religion; idem, Formations of the Secular: Christianity, Islam, Modernity (Stanford: Stanford University Press, 2003); Daniel Dubuisson, The Western Construction of Religion: Myths, Knowledge, and Ideology (trans. William Sayers; Baltimore: Johns Hopkins University Press, 2003); and Saba Mahmood, Politics of Piety: The Islamic Revival and the Feminist Subject (Princeton: Princeton University Press, 2011). 
A clue to what is at issue can be found in a footnote to Smith's essay "When the Chips Are Down," published in his 2004 volume, Relating Religion. ${ }^{23}$ He observes that he has used the language of "rectification" over the course of his career in two senses. In earlier essays it refers to the work of religious actors as they confront incongruity; more recently, it refers to his own work as a scholar in contending with "the history of scholarship." 24 In "Religion, Religions, Religious," he implicitly introduces yet a third sense - the rectification of a history of violence.

The first paragraph reads as follows:

In the second earliest account of the "New World" published in English, $A$ Treatyse of the New India (1553), Richard Eden wrote of the natives of the Canary Islands that "At Columbus first coming thether, the inhabitants went naked, without shame, religion or knowledge of God." In the same year, toward the beginning of the first part of his massive Crónica del Perú (1553), the conquistador-historian Pedro Cieza de León described the north Andean indigenous peoples as "observing no religion at all, as we understand it ..., nor is there any house of worship to be found." While both were factually incorrect, their formulations bear witness to the major expansion of the use and understanding of the term "religion" that began in the sixteenth century and anticipate some of the continuing issues raised by that expansion: (1) "Religion" is not a native category. It is not a first-person term of self-characterization. It is a category imposed from the outside on some aspect of native culture. It is the other, in these instances colonialists, who are solely responsible for the content of the term. (2) Even in these early formulations, there is an implicit universality. "Religion" is thought to be a ubiquitous human phenomenon; therefore, both Eden and Cieza find its alleged absence noteworthy. (3) In constructing the second-order, generic category "religion," its characteristics are those that appear natural to the other. In these quotations this familiarity is signaled by the phrases "knowledge of God" and "religion . . . as we understand it." (4) "Religion" is an anthropological not a theological category. ${ }^{25}$

Smith's posture in the essay is to accept the mantle of points 1 and 2. Point 1: Religion is not a native category. Point 2: Religion is, in the way Smith will use it, universal. He lines himself up with the colonizers until, by the terms of point 3, he stands against them. Point 3: Religion, as generic, will uproot what appears natural by revealing itself to have no characteristics. Point 4 is Smith's maxim for this standing against. Religion is an anthropological not a theological category.

This initial summation is not yet quite right, however. It is not by the terms of point 3 alone that Smith stands against the colonizers. We do not have to wait until point 3 to see how Smith emends them. Smith stands with them in points 1 and 2

${ }^{23}$ Smith, "When the Chips Are Down," Relating Religion, 1-60.

${ }^{24}$ Ibid., 57 n. 107. In drawing out rectification in Smith, I am indebted to William Arnal, whose views on the centrality of the notion for Smith were articulated in a memorable conversation.

${ }^{25}$ Smith, "Religion, Religions, Religious," 179-80. 
only by making them stand with him. Point 4 is Smith's maxim for the substitution of his terms for theirs.

Consider these moves and the questions they raise. Points 1 and 3: " "Religion' is not a native category. It is not a first-person term of self-characterization." Yet, is it not native to the colonialist writers? As point 3 indicates, the characteristics of the category "religion" are those that appear natural to the other, that is, natural to the one using the word religion for another or finding it absent. The colonialists can find no religion where they are looking. They are using their own concept for what they expect to be there - themselves and not-themselves, the double-mindedness characteristic of domination. But note the additional oddity of point 3 . What Smith asserts - religion appears natural to them - he also denies - religion is constructed as a second-order, generic category, and thus has no appearance. Does the fact that the word religion is "imposed from the outside" to find "them" (the natives) without it mean, of necessity, that it is, as the generic would suggest, outside even the one who is imposing it (the colonialist)? Why not say colonialists use a first-person term to denaturalize and thus conquer the other? Why make religion in the mouth of the colonialists an "anthropological not a theological category" (point 4)? $?^{26}$

Let us look at point 2. The colonialists" "religion" is "implicitly universal." Religion is "thought to be a ubiquitous human phenomenon." Therefore its "absence is noteworthy." To use the terms of point 3, the idea of a universal religion "appears natural" to the colonialists, which is equally to observe that they discover an exception to it. In this line of theoretical thinking, the universal that is natural deploys two terms (universal, natural) that encrypt what is in fact particular to a certain worldview. To identify thinking as "implicitly universal," like the use of "appears" to qualify "natural," is to observe the exception that unmasks the fabrication the words involve. There is nothing natural about the ascription of universality; there is nothing universal about what appears natural. Smith, though, reverses the drift of the thinking here, which might have seemed to take issue with the nomination of universality as such. He holds, rather, that the colonialists were not wrong in thinking religion a ubiquitous (universal) human phenomenon. They were wrong in finding it absent. Religion is ubiquitous, if in a sense different from what the colonizers meant. They were "factually incorrect" about this.

Why not say that the colonialists were factually correct that what they meant by religion (qua specious universal) was absent? Why slip a generic ubiquity into the scene in order to find them guilty, not only of universalizing what they believe but also of not universalizing enough - that religion can be found everywhere and always, not as history but as second-order category?

What Smith means when he says that religion is an anthropological and not a theological category is that it is born of the confrontation with an Anthropos, not a Theos. Religion is born of confrontation. This is an almost immaculate move. Smith locates the concept of religion (the concept presupposed by a study of religion)

${ }^{26}$ Ibid., 180. 
at the exact moment when religion is used in conquest. He places himself at that very moment in prompting us to ask how he, in promulgating his own (concept of) religion, will avoid being yet another colonialist. He responds not by offering some better concept of religion but by showing the colonialists to be the unwitting authors of his position, the position of scholarship. First move: The scholar is to be conscious of what the colonizer was blind to - that he (colonizer) is "solely responsible for the content of the term." The scholar can then tacitly grant himself a deed to that responsibility. But there is a second move. The difference between the scholar and the colonizer does not lie in consciousness. The scholar himself might after all become a conscious colonialist. The difference lies in the word, religion, which withers to an arbitrary sign.

The colonialist is like the scholar, then, in being solely responsible for the content of the term. But the identity of colonialist and scholar presumes two notions of responsibility. That the colonialist is solely responsible means the word religion has solely his meaning. It does not depict the other. That the scholar is solely responsible means the word religion can have all meanings. It shall depict the other-in being conscious not to do so in terms that privilege a particular culture. The identity of the two positions of scholar and colonialist is paradoxical, therefore, in that they are opposed. Will not the scholar have to be the one to show how you move from one responsibility to the other-how you get from "solely his" to "all"?

This takes us back again to point 3: "In constructing the second-order, generic category 'religion,' its characteristics are those that appear natural to the other." The colonizers used the word religion in a way that seemed natural to them. Like many critics of the West who have also read deeply in Enlightenment philosophy, natural, for Smith, is just another word for confrontation. If a word/concept/thing is natural to me, it is not going to be natural to you, or to some collective you. More sharply, I will use what is natural to me to deprive you, or find you in default, of the natural. Is it the word alone that is dominating or are words simply agents of the commitments we bear to others? Unlike the words universal and religion, which Smith appropriates for his own use, his truck with the natural assumes the term's signification of perfidy without indicating any interest in revising it. But like the word nature, religion is a red flag for the confrontation at stake. It would not then be a matter of redefinition in the hopes of happening upon one that would elude the dynamic of domination. What Smith holds is that, as with the universal, I elude this dynamic if all characteristics are withheld from the word altogether.

In short, since there is no getting around the politics of words, the move from conquest to scholarship cannot mean either that I merely reform myself or that I merely reform the word. I reform both-by showing that all reformations are solely mine. Smith thereby makes the responsibility of definition central to scholarship. But he locates the inspiration of defining, and thus the structure of scholarship, with the purveyors of the factually incorrect, with those he ostensibly leaves behind. Religion becomes generic. Yet note: it does not become generic because the generic 
will intrinsically avoid domination. The generic is, ex hypothesi, born in domination. It becomes generic because domination renders all of its meanings mute. Religion will have no meaning but the one the scholar gives it, because only then will the scholar have to stand responsible for its effects. Religion has no definition, which means I must define it. It is then me who is on the line, dividing myself from others, although, just in the nick of time, there is, it turns out, no line. Religion is universal. They, colonialist no less than colonized, are just like us.

I part with Smith to claim that there is a missing move here. You do not get from colonialism to theory, from "solely his" to "all," without a fight. Scholarship is wrested from conquest. But does not conquest first require critique? Smith's is a fascinating gesture to transpose a term into the key of scholarship in the very moment of its corruption. He reserves the drama of this move for the theorist, who learns that religion is not a first-person term of self-characterization but a category imposed from the outside on some aspect of native culture. Yet, is it not truer to say that religion is not a first-person term of self-characterization in these early modern texts in that it is a first-person term of other-characterization? It is an imposition, yes, but not yet a second-order "category." Smith slips the end-of second-order, of scholarship — into the beginning without comment. He is silent on how this is possible.

One avenue could be to expose the liberties European philosophes and adventurers took with their own traditions of religion as enlightenment. A reader of those traditions could supplement religion in its invidious usage with alternate histories that show the irony of its serving as a tool of oppression. This would be to conceive of the colonial contest as also a contest with the oppressor's own inheritance, a story that has colonialism "knowing" what it is deforming - the true universal of democratic self-consciousness and self-critique, universalizable in being true, not in being factual or generic. ${ }^{27}$ This is a knowing in the sense qualified by the recognition that self-consciousness might equally be self-deception. Smith seems to start with this intuition in locating the word religion at the moment of its deformation, though he will then sequester true religion on the other side of a historical divide. Prior to the moment of confrontation, the word religion is "irrelevant," he says. It is merely a term local to a particular confessional regime. In the early modern scene, by contrast, religion the thing and the deformation (knowing and its subversion, scholarship and politics) come into existence together

\footnotetext{
${ }^{27}$ Included here would be those figures, from Spinoza to Martin Luther King, Jr. to present-day critics and artists, for whom the violence of both religion and secularism are in principled relation - as disavowal, profanation - to a polity of peace and mutual respect. See, for example, A Troubling in My Soul: Womanist Perspectives on Evil and Suffering (ed. Emilie Townes; Maryknoll, NY: Orbis Books, 1993); Hortense J. Spillers, Black, White, and in Color: Essays on American Literature and Culture (Chicago: University of Chicago Press, 2003); Judith Butler, Giving an Account of Oneself (New York: Fordham University Press, 2005); James H. Cone, The Cross and the Lynching Tree (Maryknoll, NY: Orbis Books, 2011); Joseph R. Winters, Hope Draped in Black: Race, Melancholy, and the Agony of Progress (Durham, NC: Duke University Press, 2016); and Lin-Manual Miranda's Hamilton: An American Musical (premiered 2015).
} 
and shall be, from one angle, indistinguishable. They come into existence together as the confrontation that is both tyranny and its image in the word religion. The conceptual, not to say political, mess this creates can be sidestepped, or rectified, to use Smith's word, by theory. Instead of Hegel's version of the myth of the Fall, in which knowledge bespeaks the "labor, toil, and mortality" of consciousness, Smith's would be the myth of the phoenix: knowledge heals the wound by selfimmolation. ${ }^{28}$ Early-modern religion cannot be saved. Long live religion.

Smith's history of theory downplays the simultaneity his position suggests by making the story a temporal one. Once religion meant $\mathrm{x}$ (theology, confession, first order). Now it means z (anthropology, second order). But this is clearly not right, in at least two senses. First, the grip of the first order and its political interests, Smith surely knows, cannot be set aside this readily. Second, if religion, as second-order, is born in confrontation, religion, together with its scholarship, would always also be a first-order wager of its own.

\section{The Opponent}

The distinction between first-order and second-order usages functions in religious studies to separate religious-insider discourses from the science of religion. There are good arguments both for and against this distinction. ${ }^{29}$ My approach here is to redirect by connecting Smith's ideas to work in critical theory that makes the relation between scholars and their intellectual quarry — or, in short, the conditions of critique in the light of violence - part of the criticism. ${ }^{30}$ This is a connection Smith's work invites, even if it serves to highlight his difference from it. ${ }^{31}$

Let us look at the first part of the second paragraph in "Religion, Religions, Religious":

The term "religion" has had a long history, much of it, prior to the sixteenth century, irrelevant to contemporary usage. Its etymology is uncertain, although one of the three current possibilities, that it stems from the root *leig meaning "to bind" rather than from roots meaning "to reread" or "to be

${ }^{28}$ Hegel, Lectures, 106.

${ }^{29}$ See Nancy Levene, "Marx's Eleventh Thesis and the Politics of the Study of Religion: Lessons from The Sacred Is the Profane," JR 98 (2018): 224-46.

${ }^{30}$ Said's work, pursued in connection with Smith in the next section, is only one case. The critical theorists of the Frankfurt School made violence central to their thinking. More recently, critical theory encompasses critical race theory and related work on gender, sexuality, globalism, and neoliberalism. All of these conversations begin with the question of what kind of critical practice is possible once it is clear that reason and language are imbued with histories of violence.

${ }^{31}$ For a reckoning with Smith's "ambivalence" concerning a scholar's commitments, see Hugh Urban, "Making a Place to Stand: Jonathan Z. Smith and the Politics and Poetics of Comparison," MTSR 12 (2000): 339-78, at 342. Urban argues for making such commitments explicit-that "the comparative study of religions should be - and in fact always already is - an interested comparison, one which is always rooted in the scholar's own political interests and normative commitments, and which is always in one way or another deployed in the service of those commitments" (343) [italics in original]. 
careful," has been the subject of considerable Christian homiletic expansion from Lactantius's Divine Institutes (early fourth century) and Augustine's On True Religion (early fifth century) to William Camden's Britannia (1586). In both Roman and early Christian Latin usage, the noun forms religio/ religiones and, most especially, the adjectival religiosus and the adverbial religiose were cultic terms referring primarily to the careful performance of ritual obligations. This sense survives in the English adverbial construction "religiously" designating a conscientious repetitive action such as "She reads the morning newspaper religiously." The only distinctively Christian usage was the fifth-century extension of this cultic sense to the totality of an individual's life in monasticism: "religion," a life bound by monastic vows; "religious," a monk; "to enter religion," to join a monastery. It is this technical vocabulary that is first extended to non-Christian examples in the literature of exploration, particularly in descriptions of the complex civilizations of Mesoamerica. ${ }^{32}$

Before the sixteenth century, religion is 1) "true religion" (Christian homiletic expansion of the root "to bind") and 2) a cultic term implying "the careful performance of ritual obligation" as well as, by extension, the totality of monastic life. In keeping with his claim that the religion of confrontation is anthropological and not theological, Smith says that the first is "irrelevant to contemporary usage." The rest of his essay follows the modern history of the early Christian cultic usage, "altered" in time to include things like piety, reverence, virtue, and knowledge, though his story indicates this is more an augmentation than an alteration. ${ }^{33}$ Religion comes to oscillate between being a term of practice/cult and one of mental attitude/ belief, with Eden representing the latter and Cieza the former. Smith's interest, we have seen, is in the effort in Western Christendom to deploy the term religion to account for the differences of other peoples. He also observes the Christian struggle to account for its own internal diversity and traces therein the slow evolution from confrontation with diversity to the internecine theo-politics of classification, at the end of which stands Smith's own work. As he does with the colonialists, Smith makes allies among his enemies, finding diversity, wherever it is found, to be a potent solvent of invidious, colonialist thinking. The struggle with diversity will be, ultimately, edifying.

Although Smith holds that the pre-sixteenth century usages are largely irrelevant, then, he connects one of them to the usage he shares with, in subverting, the colonialist authors. Religion is an extension: The colonialists were would-be anthropologists, riffing on the hybridity of their inherited concepts. Religion is an invention: The colonialists were would-be map-makers, whose product can be symbolically reversed. In each case, Smith allows for continuities in the long history along with the freedom to correct the story.

\footnotetext{
${ }^{32}$ Smith, "Religion, Religions, Religious," 180.

${ }^{33}$ Ibid., 181-82.
} 
What is notable in Smith's argument is his distance from the case-his fluency in correction without the riskier work of critique. Critique here means not only taking on the conquistadors, which Smith does, but also working through one's proximity to the thing. Smith locates himself at the end of a history of religion that serves as the backstory to his powers of reversal. However, in making the usages of Lactantius and Augustine irrelevant (merely "homiletic") to the study of religion, he recuses himself from the Western Christian and Enlightenment and post-Enlightenment struggles with the object the conquistadors deploy in violence. Smith picks up on the violence, in the face of which one makes historical what passes for perennial-universal. Concepts have histories, by which one observes their competing meanings. As in Smith's pedagogy, this is a training in skepticism, the drama inhering in the reversal of a concept's face value. But what of a concept, a story, that does not require reversal? What of the concept of history itself, in which the aim is not only to outwit the opponent, but to locate whence the opposition arises: to locate oneself in a relation of opposition and to theorize and even rectify it?

Smith's recusal sidesteps the usage that culminates in the Western confrontationnot with other religions but with its own. If religion makes the knowledge of other peoples possible (and impossible) in the age of exploration, it is at the same time its own radical impossibility. As with Hegel and his telling wound, religion in the philosophical and theological West is figured as a confounding desire, at once a discipline of the mind and a temptation to obliterate it. This religion is hardly the domain simply of a cultic and confessional past, being central to problems psychical, social, and political beginning in the antiquity of the Mediterranean worlds, the site of Smith's own scholarly expertise. Theologians like Augustine and Pascal share with Hegel a concept of religion as critical confrontation with desires both creative and destructive of human reality. By their account, religion is an expression of uncertainty no less than adventure in disclosing to human beings that the obstacles to knowledge of the world begin, as it were, at home. Are such "homiletic" excursions irrelevant to the confusions of conquest and Smith's canny theoretical reply? This would be so only if you have decided that conquest replaces the struggles expressed by the concept it so dumbly deploys, only if you have affixed the word religion to colonialism, and not also to criticism.

Smith is not quite in the belly of the thing, despite his interest in confrontation as a birthplace and his willingness to be continuous with it. Religion prior to the sixteenth century is irrelevant to contemporary, that is, anthropological usage. But if anthropological religion in Smith's conceptual vernacular is forged in the crucible of confrontation, then his temporal account would not hold. Anthropology would not replace theology; it would be at war with it, as theology is at war with itself. One is bound to be troubled by the conquest of native others named by the word religion. In close proximity, however, are religion's conquests of intimate life in the name of faith and love. If we can assign scholarly authorship to, by ventriloquizing, the conquistadors, why can we not do the same with Augustine or Lactantius or the 
biblical authors? Even more, in the model of ventriloquism, Smith's co-authorship with his colonialist enemies leaves them dutifully opposed to him. By contrast, to activate "homily," Smith perhaps intuits, will require the admission of a more intimate opponent, one that cannot be so neatly reversed. Cannot critique itself always also be or become mere homily? Cannot theory always also be or become domination? Are Augustine and Lactantius, with their "true religion," irrelevant because their concepts are not usable for scholarship, or because we do not want, and think we can escape, Said's anxiety of whether they will get the better of us?

In Smith's model, we theorists risk being colonizers only for the split second it takes to recognize that there is no danger of being so. The model is that their (the colonizers') "religion" is the position which vanquishes religion-as-colonialism, insofar as it can be fabricated as a second-order concept. At the same time, religion is already a fabrication. It is paradoxically already a second-order concept-it is already the position of scholarship - only in that it was never anything but colonialism. The colonialists, in other words, are blind to what they are doing - not to colonialism, which they perpetrate in a common way, but to the revolution of the word for which Smith gives them perverse credit. This blindness is why we, or rather Smith, can serenely reread them, rather than having to wrestle them to the ground. What is common is that Eden and Cieza colonize by reaching for a term meant to include the other, only precisely to deny the other in saying: "They have no religion. They are not like us." This move would be Orientalist in impulse. In choosing the word religion for "them" only to find it absent, the colonizers make themselves the measure of all things.

For Smith, however, the word religion not only fails to include the other. It also fails to include its authors, who can therefore be deprived of it as it is purloined by scholarship. In my terms, Smith's religion is not quite criticism, which would show the colonialist move to be inescapably confrontational for the critic. For Smith, religion is the property neither of the West nor its others. Even the colonizers are not in possession of the thing they use. It is not that they are unconscious that they make themselves the measure of all things. They are, blindly, not the measure at all. Orientalism gives rise to the form of the generic religion, which has no author.

It is a striking theoretical move. But - it will be clear-there is more to it than it quite explains, more to the attribution of blindness than factual correctness or incorrectness. Smith's use of the terms "anthropology," "generic," and "secondorder" are polemical. He needs what the colonialists observed of the natives-that they have no religion - to be untrue because of what this observation entaileddomination, colonialism, dehumanization - even as he acknowledges the truth of what they meant, which is that "they have no religion like ours." He therefore needs to assert that the natives do have religion, for which one needs a generic concept, because "like ours" (the colonialist first-order, theological concept) will not do as a term of comparison. The colonialist universal cannot be universalized because it is exclusive of the other, and so it must, as it were, have its proper universality 
imposed in the form of the generic. Smith makes this imposition a matter of history: "It is the question of the plural religions (both Christian and non-Christian) that forced a new interest in the singular, generic religion." 34 But it is Smith whose interest in the generic is forced by the plural religions in conflict. His early modern European protagonists were interested in the plural religions. But it is not true that they thereby ascended to a generic. It is not true that they ever escaped the judgment "not like ours."

It is indeed because the relationship between scholarship and politics is so vexed that we need the reparative, strategic works of Jonathan Z. Smith. In this, his signal essay on the origins of religion, however, Jonathan Z. Smith also needs Jonathan Z. Smith, because at least one of them knows that you do not ascend to a generic in the operation of "not like ours" without a critique of the opponent, who might also be you. Critique is the struggle for interpretation in which it is always possible to fall on your own sword. Sometimes our opponents do hand us the tools for their own demise. But they do not work the blades without us.

Smith's position appears a perfect revenge. The dynamics of conquest are not only foiled in being called out but are put to scholarly use - the compost where more productive research might grow. It is a sharper move than Durkheim's claim that the civilized possess nothing elemental that simpler cultures do not, though the two thinkers are part of the same genealogy. ${ }^{35}$ But it is also obfuscation: scholarship and its colonialist authors appearing together to tilt into the mess they also clean up. It is Smith who curates the move without quite making it; Smith who gives his authorship away in order to get it back on cultically purified grounds, meaning that, in Smith's model of reversal, he himself can never be wrong because never right: never in proximity to truth - of religion or anything else. Smith's is a rejection of colonialism in virtue of the judgment that the word religion does not name the thing. No word does, but in the case of religion, this mismatch leaves us the freedom not only to admit the mismatch as a permanent danger — as skepticism requires - but to freeze the system: to separate scholarship and politics and then to subsume the latter in the former. He does this perhaps to model the most effective temper. Let us not become revolutionary guards, the opium of the colonialist. He wants to be done with the fight and to get on with the repair. For this we need calm heads. We need to forget that we are theorizing in strategic response to something wounding.

It is worth not forgetting, however, that politics and scholarship, like conquest and free relation, come into existence together. Their opposition is made - and unmade - in theory. But therefore, the relationship of conquest and freedom has to be worked out at their common root, or the bellicose dynamics will merely repeat below the manoeuvers of the generic.

${ }^{34}$ Ibid., 182.

${ }^{35}$ Emile Durkheim, The Elementary Forms of Religious Life (trans. Karen E. Fields; New York: Free Press, 1995). As Durkheim writes in the introduction: "Fundamentally, then, there are no religions that are false. All are true after their own fashion: All fulfill given conditions of human existence, though in different ways" (2). 
The question to Smith might be: Why salvage religion at all? Why not let the word go down in the flames set by the conquistadors? If it is the politics of words and actions you want to study, why not just study them without reclaiming this word? It might be the question for religious studies today. Why is it religion one studies? Is it not rather too much effort to take a word that has always meant, more or less, a limited family of things and get it to mean - in this case no family of things, or any family of things? To take a word that means something and get it to mean anything or nothing? Smith would have it that religion is a "second-order, generic concept that plays the same role in establishing a disciplinary horizon that a concept such as 'language' plays in linguistics or "culture' plays in anthropology." ${ }^{\text {"36 }}$ But can this horizon for religion be established through a generic? Like many who inherit the spirit of his work, Smith is inclined to restrict other usages even as he underscores that such usages are near-infinite. ${ }^{37}$ No one gets to command the horizon. We can certainly now see why this is, in seeing why to rescue religion in particular. One must not, in memory of those natives, let the bastards have the last word. Smith seems to go further. We let the bastards have our word. But in working on the relationship between violence and theory, this misplaces, in hastening, the conclusion.

\section{Power and Interpretation}

I suggest a different conclusion through a comparison of Smith with Said, reexamining in the process Nietzsche's concepts of genealogy, power, and interpretation. ${ }^{38}$ Said's critique of Orientalism operates with these concepts, as well as with immanent critique, the exposure of a system's principles and contradictions. In addition, Said points his work, as Smith does, toward a dilemma of scholarship: how to understand in light of the urge to correct. Said is more responsive than Smith to the question of where you stand in relation to the thing you are observing. ${ }^{39} \mathrm{At}$ the same time, if Smith makes too swift a move to save scholarship from colonialism, Said gets bogged down in the problem to which Smith's reply is so decisive. What

${ }^{36}$ Smith, "Religion, Religions, Religious," 194.

${ }^{37}$ On policing other usages, see Smith, "Fences and Neighbors: Some Contours of Early Judaism," in Imagining Religion, 6-7. On the endlessness of valid usage, see idem, "Religion, Religions, Religious," 193-94. See also Russell T. McCutcheon, "Relating Smith," review of Smith, Relating Religion, JR 86 (2006): 287-97, and idem, "Introducing Smith," in Introducing Religion (ed. Braun and McCutcheon) 1-17.

${ }^{38}$ For another concept of genealogy and its utility in thinking with Smith, see Gregory D. Alles, "Cargo Cult Science and the Study of Religions: Genealogy in an Age of Globalization," in Introducing Religion (ed. Braun and McCutcheon) 18-39.

${ }^{39}$ In "The Influence of Symbols on Social Change: A Place on Which to Stand" (in the essay collection Map Is Not Territory: Studies in the History of Religions [Chicago: University of Chicago Press, 1978] 129-46), Smith distinguishes the historian, who has no place to stand "apart from the messiness of the given world," from the philosopher or theologian, who can access "a standpoint from which all things flow" (129). As Urban counters, Smith's work nevertheless evinces a consistent set of values concerning the power of human beings to manage the difficulty of the world ("Making a Place to Stand," esp. 359-66). 
do we do with problematic words and fabrications given our own authorship, our own implication in the power of interpretation?

Said's Orientalism (1978) is a canonical work in postcolonial studies, the investigation of the social, political, and economic implications of the West's domination of cultures and peoples. As an academic project, postcolonialism took root in the wake of Franz Fanon's two studies of psyche and society in the light of colonialism and racism: Black Skin, White Masks, published in 1952, and The Wretched of the Earth, published in 1961. These works were themselves written in the light of movements toward independence from colonialism and theoretical critiques of it. ${ }^{40}$ Postcolonial studies considers the institutions and ideas supportive of asymmetrical power relationships and the discursive dynamics that work against liberation, whether social or psychical. It emerged both to celebrate liberatory movements in formerly colonized domains and to caution that political liberation is only part of an ongoing struggle to address the causes and long-term effects of domination and subjugation. The West of this writing is a behemoth and equally a figure of fantasy and myth — of the European, of whiteness.

Said offered this milieu its quintessential manual. Yet although Orientalism concentrates the themes of its zeitgeist, there is a vagueness in Said's sense of historical moment, connected to the anxiety of criticism. What is the relationship between a specifically Western archive and some set of universal dilemmas and temptations? How can critics be sure they are free of the Orientalist move? What is the value of a critique that is not free in this sense? Said ultimately felt that his argument, though influential, was misrepresented. ${ }^{41}$ This misrepresentation may not only impugn Said's critics, however. The book leaves open the question, Orientalism compared to what? It could be said that twentieth- and twenty-firstcentury theories of violence as a blindness intrinsic to modern reason circulate without end precisely because they stop short of working through to the conceptual scaffolding. One states and restates the extent to which ideas and ideals oppress, but the work to articulate responses is easily enough short-circuited in any critical project in which the problem is the tool of critique itself.

Smith, we have seen, recovers a usable theory by removing the question of politics from scholarship altogether. Said is more, let us say, confrontational. The acknowledgements to Orientalism indicate that Said wrote it during the years 1975 and 1976 when he was a fellow at the Center for Advanced Study in the Behavioral Sciences at Stanford University, conjuring the peaceful, removed milieu of which

\footnotetext{
${ }^{40}$ Franz Fanon, Black Skin, White Masks (trans. Richard Philcox; New York: Grove, 2008); idem, The Wretched of the Earth (trans. Richard Philcox; New York: Grove, 2005).

${ }^{41}$ In an afterword to the 1994 edition of Orientalism, Said responds to "misreadings" and "misinterpretations" ([New York: Vintage Books, 1978, 1994] 329-52, at 330). He revisits the issue in his May 2003 preface to the $25^{\text {th }}$ anniversary edition of the book, a few months before he died (xv-xxx, at xv). In Edward Said: Continuing the Conversation (ed. Homi Bhabha and W. J. T. Mitchell; Chicago: University of Chicago Press, 2005), a collection of Said's colleagues, students, and contemporaries strive to keep Said's work from the caricatures to which it was subject.
} 
some fortunate scholars can periodically avail themselves. However, the image of Said the scholar, removed from the tumult and controversy to which his name would be appended, is at once a confession of his privileged place in the upper reaches of the ivory tower and also wholly inadequate. Like the Orientalists he exposes, his is a decidedly engaged authorial presence. From the introduction, which begins with the figure of a French journalist in the "gutted" downtown Beirut of the 1970s, to the emplacement of Orientalism at the center of the most pressing global issues, from oil, to foreign affairs, to anti-Semitism, Said's was never meant to be just another scholarly work on the history of the West. When one says "postcolonial," one means - Said showed what it is to mean-a work of politics as well as scholarship; an intervention; a salvo.

Said's wager is that "everyone who writes about the Orient must locate himself vis-à-vis the Orient." ${ }^{\prime 2}$ In the strict sense, he is referring to the task of analyzing the "ensemble of relationships between works, audiences, and some particular aspect of the Orient" which has authorized the Orientalist in his effort to speak on behalf of the Orient. But Said does not exclude himself from this task of location, taking inspiration from Gramsci's exhortation to know oneself "as a product of the historical process to date" and thus, in taking "inventory" of this process, to find ways to speak to and for one's time. ${ }^{43}$ If Said does not say whether the modern West is intrinsically villainous, his work as an immanent critic would suggest that this cannot be the case. The phenomenon of Orientalism is a potent brew of the scholarly and the political, the philological and the material. Its deconstruction will require nothing less than a similar set of arms, recovered from those at hand.

Early in the introduction, Said advances "a more general meaning" for Orientalism than the one given by academic specialization and deployed by corporate and political institutions. "Orientalism," he holds, "is a style of thought based upon an ontological and epistemological distinction made between "the Orient' and (most of the time) 'the Occident." "44 This distinction is "accepted" by "a very large mass of writers, among whom are poets, novelists, philosophers, political theorists, economists, and imperial administrators," who take it as "the starting point for elaborate theories, epics, novels, social descriptions, and political accounts concerning the Orient, its people, customs, 'mind,' destiny, and so on." If discourse names the mode whereby such writers and actors Orientalize the other, the basic distinction between Orient and Occident, accepted and elaborated, has no clear provenance. In the history of its usage, Orientalism appears in multiple locations, inclusive of "Aeschylus, say, and Victor Hugo, Dante and Karl Marx."

\footnotetext{
${ }^{42}$ Said, Orientalism, 20.

${ }^{43}$ Ibid., 25.

${ }^{44}$ Ibid., 2.

${ }^{45}$ Ibid., 2-3.

${ }^{46}$ Ibid., 3.
} 
It is intuitively satisfying to designate the distinction between Orient and Occident an ontological one. They are non-overlapping, as in Durkheim's sacred and profane or Smith's scholarship and politics. Said's conceptual modification of this structuralism is represented by what he calls epistemology: the world as it is, taken — "accepted"- as some world in particular. The very idea of discourse is mounted on the grounds of an "epistemological" correction of the "ontological," the assumption, namely, that they are effectively the same, that the world is what we take it as. This leaves open the question of how one might take the world otherwise. We have seen Smith's response. We simply do it, take it otherwise, correct it. Fabricate.

Said drags his feet. His sense of urgency lies in the proposition that Orientalism is an overwhelmingly comprehensive determination of the world vested in one very particular set of perceptions and practices. But the question of whether the world is actually some other way; the question of what it would mean not only to notice how we have taken it and to take it otherwise, but to seize hold of this structure of "is" and "as" in order to inquire about the principles of one's taking; the question of the obligations not only to this history of Orientalism but also to history as such-Said does not ignore these matters. However, he brings to them the philosophically tangential point of the relentlessness of his cases, as if to stay our hand. In this he is tracking his object. Unlike the diversifications that Smith finds edifying, Orientalism diversifies to no clear end, possessing an "indiscriminate size plus an almost infinite capacity for subdivision." It is a voracious map, an orphaned dualism (there is no Occidentalism), a "confusing amalgam of imperial vagueness and precise detail." It is not only that Orientalism immodestly takes on "a full half" of the world or that it divides the world in two. ${ }^{47} \mathrm{It}$ is that Orientalism encompasses both the half of the world it studies and the half of the world from which it studies it. It is a total vision of reality, the West understanding itself - and manifestly failing to understand itself - through its other. Again, Ashbery: "It is you who made this, / therefore you are true. But the truth has passed on / to divide all."

How do you address this vision? The question put to Smith is: How do you recover concepts born in violence? The question to Said is: How do you rid yourself of bad concepts? The momentum of discourse acquired through the identification of ontology and epistemology keeps Said's gaze trained on the multiplication of cases, but in hindsight this decision reads like a stall. He leads readers to conclude that what led him to infiltrate the operating system of scholarship is this seemingly inarguable but vaguely delimited multiplication. It is notable, then, that, of all the disciplines influenced by his work, history has been least absorptive. The historian can always out-multiply the critic: The history is simply more complicated than you depict it. Here is what and whom you left out. Here are the angles you missed, the cases you slighted, the method and the archive to which you were unfaithful. ${ }^{48}$

${ }^{47}$ Ibid., 50.

${ }^{48}$ For historians who have engaged with Said, see Suzanne L. Marchand, German Orientalism 
Said's invocation of ontology and epistemology, as fragmentary as it is, nevertheless assists the key questions at issue here. There is, first, the question of confrontation. Who is confronting whom? There is, second, the question of theory's investments. What do you do with bad maps? There is, third, the question of teaching, the question of what is shared and how. In quest of principle in the comparison of Smith and Said, let us consider Nietzsche's response to these three questions in the second essay of On the Genealogy of Morals. The essay is on guilt and the bad conscience, imaginatively considering the origin of law, duty, indebtedness, justice, religion, and the origin of origin itself. In one well-known aphorism on punishment, Nietzsche makes a distinction between its "origin and purpose." Although "previous genealogists of morals" have understood punishment to have its cause in some particular purpose, "for example revenge or deterrence," Nietzsche counters that " 'the purpose of law' is absolutely the last thing to employ in the history of the origin of law." He issues a generalizable maxim:

the cause of the origin of a thing and its eventual utility, its actual employment and place in a system of purposes, lie worlds apart; whatever exists, having somehow come into being, is again and again reinterpreted to new ends, taken over, transformed, and redirected by some power superior to it. ${ }^{49}$

On the one hand, both theorists can be comprehended in Nietzsche's terms. Smith practices Nietzsche's maxim that the origin of the thing and its utility are "worlds apart"; indeed, they are opposed. Said's project is informed by Nietzsche's conception of interpretation. Orientalism emphasizes what Nietzsche calls the "fluid" aspect of an event or phenomenon, what can be taken up and taken over"mastered" - through a "fresh interpretation," whereby "any previous 'meaning' and 'purpose' are necessarily obscured or even obliterated." 50 Said stands with Nietzsche in pursuing, again in Nietzsche's words, the "spontaneous, aggressive, expansive, form-giving forces that give new interpretations and directions" to the ideas and systems of our worlds. ${ }^{51}$ Smith stands with Nietzsche in identifying with the colonialist, only to purge force from the scene.

On the other hand, neither theorist articulates the principle on which Nietzsche's gap is based. Said downplays the implication that interpretation, as a stance of power, would not be controllable by a single domineering opposition, Orient and Occident, and would not necessarily privilege only one side. Smith uses opposition itself to escape domination but then hides his principle: that if punishment is not necessarily revenge, theory will be.

in the Age of Empire: Religion, Race, and Scholarship (Cambridge: Cambridge University Press, 2009); Urs App, The Birth of Orientalism (Philadelphia: University of Pennsylvania Press, 2010); and Orientalism and the Jews (ed. Ivan Davidson Kalmar and Derek J. Penslar; Waltham, MA: Brandeis University Press, 2005).

${ }^{49}$ Friedrich Nietzsche, On the Genealogy of Morals (trans. Walter Kaufman; New York: Vintage Books, 1967) §12, 77.

${ }^{50}$ Ibid.

${ }^{51}$ Ibid., 79. 
What is the moral of a genealogy of morals? Interpreters struggle with Nietzsche himself on this score. Might anyone at any time initiate a new interpretation of something seemingly stable, as Nietzsche does with the valuations good and evil? Do origins constrain interpretation in any way? Can the origin of a thing, its "having somehow come into being," even be a subject of inquiry, or does the conviction that interpretation is ceaseless - "spontaneous" and "aggressive"-imply that origin is effectively annihilated as an investigative avenue? This latter is the preemptive strike of the generations that fasten on genealogy as an insight into the fundamental historicity of things: that "is" and "as" are the same; that the world just is how we take it, with nothing there to ground better or worse ways. But like Said and Smith, Nietzsche is interested in the relationship between "is" and "as," between origin and purpose. Cutting purpose adrift from origin could signal that origin is a nonentity, that "is" is only ever "as." But both Smith's gambit from colonialism to the generic and Said's multiplication of cases presuppose an alternative - a confrontation with how things are, the employment and not simply the evacuation of value.

Nietzsche's critique is of the teleological relationship between origin and purpose, the notion that we are to take the world some particular way because of the way it (ostensibly) came into being. This is the notion that the mind merely reflects or represents the real. Although this temptation might seem unlikely to a reader educated in twentieth-century critical theory, it remains challenging to delimit a worthy alternative, one that does not simply counter skepticism to teleology's dogmatism. If genealogy allows that interpretation is freely open to anyone at any time, this could bespeak the "might makes right" of Orientalism, the fluid reversals of theory. Yet both Smith and Said spur us to want more from scholarship, as from politics. Do they, together with Fanon, enable us to see how the proposition that interpretation is free might be a principle that, like free speech, is constrained by its own possibility? This would be to say that what guides interpretation is not only power but truth - what Smith calls fact, what one might call reality, what all positions here grant is ours to take as we will. It would make the freedom at issue in genealogy a shared responsibility to what is - the world as you and I and everyone else take it. If it will tend to be a struggle to occupy the same world (to say the least), this struggle cannot be circumvented without resigning the principle of one's position - the origin, the free relation, of interpretation itself.

The question is: In the interpretation of the history of religion that takes the work to be the exposure of the fabrication of values presenting as perennial, what of the value that presents as historical — genealogy itself, the interpretation of history as what corrects, in confronting, the lies of the past? In the very question is the suggestion that, insofar as it is genealogy by which such lies are exposed, it is not a generic practice but one with a specific history, a specific concept that therefore cannot be quarantined from violence. As in immanent critique, the thing and the critique begin together. But more, the history of religion would be a faith in history to bear the truth - the truth of violence and its righteous reply. In Said's terms, 
this would be to see that it is possible for the West - as for theory - to vanquish its Orientalism, its bad maps, without vanquishing itself, or, more intimately, without vanquishing oneself, scholar and conquistador of thought. To rephrase the Hegelian insight for the principle of interpretation: genealogy-history, critique, politicsrectifies the violence that it itself is.

\section{Conclusion}

Said's critique of the West is trained on its poisons, not only of geographical ambition but also of classification, about which Smith's reversal allows him to be more sanguine. Given both thinkers' truck with maps of the world, it is fitting to conclude with Said's treatment of the 1697 Bibliothèqe orientale, a posthumously published "library" or alphabetical compendium of matters Oriental by Barthèlemy d'Herbelot. Said notes that the Bibliothèqu, "the standard reference work in Europe until the early nineteenth century," was "truly epochal in scope," discussing "such widely divergent histories as the Mogul, the Tartar, the Turkish, and the Slavonic," in addition to taking in "the provinces of the Muslim Empire, from the Extreme Orient to the Pillars of Hercules, with their customs, rituals, traditions, commentaries, dynasties, palaces, rivers, and flora." 52 Said logs this prodigious accomplishment skeptically:

In such efforts as d'Herbelot's, Europe discovered its capacities for encompassing and Orientalizing the Orient. A certain sense of superiority appears here and there in what [d'Herbelot's contemporary and the author of the preface, Antoine] Galland had to say about his and d'Herbelot's material orientalia; as in the work of seventeenth-century geographers like Raphael de Mans, Europeans could perceive that the Orient was being outstripped and outdated by Western science. But what becomes evident is not only the advantage of a Western perspective: there is also the triumphant technique for taking the immense fecundity of the Orient and making it systematically, even alphabetically, knowable by Western laymen. ${ }^{53}$

Since Said wrote these words in 1978, it has become a commonplace to associate classification with hegemony, an association that Smith's reparative work in the history of religion counters. The Bibliothèque orientale was to "represent the Orient more fully and more clearly," to take "what may have been a loose collection of randomly acquired facts concerning the vaguely Levantine history, Biblical imagery, Islamic culture, place names, and so on" and to "transform" them into a "rational Oriental panorama, from A to Z." 54 Said has an ambivalent relationship with the concept of reason that is passed down through the West. He uses it in the sense of a Western ruse to hide the arbitrariness of its positions. But he also uses it as a genuine privilege denied the Orient, whose rationality is impugned, "undermined,"

\footnotetext{
${ }_{52}^{52}$ Said, Orientalism, 64.

${ }^{53}$ Ibid., 65.

${ }^{54}$ Ibid.
} 
it is claimed, "by Eastern excesses, those mysteriously attractive opposites to what seem to be normal values." ${ }^{55}$ Here Said seems both connected to and unmoored from the resources of a Hegel, the Orientalist with the most eminently mobile concept of reason. Noting that, in its entry on "Mohammedanism," the Bibliothèque distinguishes Muhammad as a false prophet, Said's attention is drawn not to the claim of falsity - boilerplate for rival religions - but to the very fact that Muhammad can have an entry at all:

it is the placing of Mohammed that counts in the Bibliothèque. The dangers of free-wheeling heresy are removed when it is transformed into ideologically explicit matter for an alphabetical item. Mohammed no longer roams the Eastern world as a threatening, immoral debauchee; he sits quietly on his (admittedly prominent) portion of the Orientalist state. He is given a genealogy, an explanation, even a development, all of which are subsumed under the simple statements that prevent him from straying elsewhere. ${ }^{56}$

The claim that we should worry no less about the Encyclopedists than about the warring priests and imams is common to postcolonial reconstructions of the Enlightenment. Europeans, Said notes, were not wrong about the "Ottoman peril," which began to fade only at the end of the seventeenth century. But his focus is on the "Western ignorance [about Islam]" that takes the form of ever "more refined and complex" theories of it, devoid of "positive knowledge." 57 His metaphor for this ignorance is the stage, calling the Bibliothèque a piece of "Orientalist theater," and suggesting further that the very act of classification in this case is an imprisoning one. The Orient is "the stage on which the whole East is confined." All fields are made. But the Orient is what he calls a "closed field," "affixed to Europe" in adventurous acts of knowledge. ${ }^{58}$

The Bibliothèque is an attractive case for Said because it looks so much like what scholars still practice as a matter of course - classification, definition, interpretation. We no longer approve of d'Herbelot's commentary on Muhammad. But the question of whether d'Herbelot's form is at root corrupt brings us to what Said and Smith share. Said writes: "there is nothing especially controversial or reprehensible about such domestications of the exotic; they take place between all cultures, certainly, and between all men." His point is to "emphasize the truth that the Orientalist, as much as anyone in the European West who thought about or experienced the Orient, performed this kind of mental operation" with a "limited vocabulary and imagery that impose themselves as a consequence." 59

The Orientalist, like the conquistador, is undoubtedly limiting and limited. What the comparison of Said and Smith asks is whether there is a way to confront the

\footnotetext{
${ }^{55}$ Ibid., 57.

56 Ibid., 66.

${ }^{57}$ Ibid., 59, 62.

${ }^{58}$ Ibid., 63.

59 Ibid., 60.
} 
gap between maps and worlds that activates the insights of both thinkers while addressing their own limitations: in the one case, repetitively multiplying the data in the face of a violent map or, in the other, facing violence just long enough to cauterize it.

What Nietzsche illuminates is not only the gap between "is" and "as," world and map, but the different responses of what he calls pessimism and the criticism he himself would practice. ${ }^{60}$ Both responses are freed from moralism to grasp the mobility of interpretation and thus the ubiquity of violence. Unlike pessimism, however, criticism also practices a defense of the real no less than an alertness to its mutations. Criticism is interpretation of reality in commitment to it. This would be a reality that, in being cofabricated, is not simply condemned to aggression, any more than human relations are in principle structured by domination. On the one hand, there would be no original position, no reality apart from the way interpreters and communities of interpreters take it. As Nietzsche puts it, "we cannot reject the possibility that it [the world] may include infinite interpretations." ${ }^{1}$ On the other hand, one fights for reality, and this fight is for "the actual world" supportive of the value, and not only the war, of interpretation. ${ }^{62}$ Aggressiveness, in interpretation as in relation, is unremarkable. But if Nietzsche's target in his genealogy is a moralism that would overwrite this truth, he is no less concerned to expose the moralism that either celebrates the genealogical reply or freezes in resentment or disappointment in face of it. Interpretation is of what is. It is also, Smith and Said remind us, an invention. It can therefore be reinvented, until one gets it right.

The question this "right" will always raise is: How do we choose among interpretations? If there is some most-true version in a world in which interpretation is absolute (and the absolute is interpretation), what would ground it - theoretically or politically? If there is some best interpretation, how would we justify it?

What can still be learned from Nietzsche's genealogy in a practice of immanent critique is the position that connects scholarship and existence, interpretation and truth, without dissolving the difference; an ethics, it could be called, that refuses pessimism in favor of criticism. Ethics might seem to fail the inconclusiveness that theory requires in order to be mobile. The power of interpretation, however, lies not in inconclusiveness but in recognition - of the ideology of the conquistadors, to be sure, but also then of their illusions, their lies. Smith responds with the shield of scholarship: given a history of violence, let us reformulate conflict as comparison. Said prefers the stance of skeptic: since interpretation is fundamental, let us not be its dupe. Either remove yourself from the violence — as in Smith's "There is no

\footnotetext{
${ }^{60}$ Pessimism is how Nietzsche describes the work of Schopenhauer, what he calls in the Gay Science "the whole pose of 'man against the world,' of man as a 'world-negating' principle" (Nietzsche, Gay Science [trans. Walter Kaufman; New York: Vintage Books, 1974] §346, 286).

${ }^{61}$ Ibid., $3374,336$.

${ }^{62}$ Ibid., $3346,286$.
} 
them," and, as Michel Foucault prophesied in a similar key, "There is no us"- - or abide in suspicion until one finds the exit, the critical theory of Said. ${ }^{63}$

Theory can be pushed further. One concept of further would involve noting that Smith and Said are both working in proximity to Foucault's sustained rereading of the history of medicine, philosophy, the human sciences, sexuality, and the social scaffolding of domination. Smith in particular shares Foucault's interest in forms of analysis that deemphasize subjectivity. It is precisely this interest that he uses to such strange effect. In Smith, the subject is not so much illusory as hidden, correcting the work of the conquistadors while remaining impossible to pinpoint. The move calls for Said, who steps into the frame, if only to stall on the unendingness of correction. It is possible to imagine this very conversation staged by Foucault courtesy of his reading of Diego Velázquez's great painting Las Meninas (1656). The theorist is invited into the picture she is also called to interpret; the map is embedded in a history it is also called to navigate. Yet, however germane is Velázquez to Smith and Said, Foucault himself is in search of alternatives to criticism. ${ }^{64}$ At the least, Smith's response takes a different turn. We are to take responsibility for what we say. The colonialists are "solely responsible for the content of the term" religion; so then Smith will assume this same mantle: sole responsibility.

This gesture is galvanizing but incomplete. As Ashbery would have it, while you are making it about you, the truth will have "passed on." The concept of theory goes further, I have argued, in the complex, even ironic commitment to reality. Otherwise stated, the subject of theoretical responsibility is never alone. Becoming responsible for what one says involves becoming responsible for what one says to someone, who in turn is charged with the responsibility of hearing it. Responsibility is constituted jointly. This claim is nothing less than Nietzsche's genealogical gambit: his abandonment of readers to infinite interpretations at the same time as he supports the struggle to disempower shams and masks and despots and liars - the liars we also are. The drama is that we will do almost anything to avoid this work, pitting one against the other: interpretation or truth.

Let us learn at least this: that I cannot have sole responsibility for a term I use to understand you (or even myself) without doing what the colonialists did in understanding nothing, a truth to which Smith is joint witness with his readers. The

${ }^{63}$ Michel Foucault, The Order of Things (New York: Vintage Books, 1994). The book concludes thusly: "As the archaeology of our thought easily shows, man is an invention of recent date. And one perhaps nearing its end" (387). On Said's illuminating struggle with the exit, see Nancy Levene, Powers of Distinction: On Religion and Modernity (Chicago: University of Chicago Press, 2017) 65-98.

${ }^{64}$ On Las Meninas, see Foucault, The Order of Things, 3-16. On genealogy and subjectivity, see idem, "Nietzsche, Genealogy, History," in The Foucault Reader (ed. Paul Rabinow; New York: Pantheon, 1984) 76-100. On violence and society, see idem, Discipline and Punish: The Birth of the Prison (trans. Alan Sheridan; New York: Vintage Books, 1995). For Foucault and the history of concepts, see Arnold Davidson, The Emergence of Sexuality: Historical Epistemology and the Formation of Concepts (Cambridge: Harvard University Press, 2004). For questions of religion and power, see Mark Jordan, Convulsing Bodies: Religion and Resistance in Foucault (Stanford: Stanford University Press, 2015). 
rectification that is solo responsibility belies this witness, attempting to bypass the inarguable truth that joint responsibility - my truth and yours-will not in itself prevent colonialism. Indeed, it may recapitulate the politics of relation essential to colonialism. It is no solution to this problem to reverse the colonialist hubris: they understood nothing; we will make nothing — the generic — what we understand. Like Said, you have to struggle with the opponent, who is not necessarily so conveniently opposed to you. By the same token, as Smith knows, you have to act. The bastards do not get the last word.

Still, they cannot be silenced. One is never finished getting it right.

Teaching religion is the consciousness of confrontation and the responsibility to understand. It must not pretend to be able to leave out the threat of colonialism permanently. What it does is wager, in going anywhere, that, in struggling for a shared world, one shall not pass on anything less. 